\title{
Physico-chemical analysis of Sugar factory Effluent stress on seedling growth of black gram (Vigna mungo (L.) Hepper) varieties
}

\author{
B. Elayaraj \\ Environmental Science, Department of Botany, Annamalai University, \\ Annamalai Nagar - 608 002, Tamil Nadu, India \\ E-mail address: belayaflora@gmail.com
}

\begin{abstract}
The physico-chemical parameters of the content in the effluents from Rajasree sugar factory of Villupuram district have been explored and its impact on the germination and growth patterns of black gram varieties has been studied. Physico-chemical parameters included color, odour, $\mathrm{pH}$, temperature, electrical conductivity, suspended solids, dissolved solids, BOD, COD, chloride, sulphate, calcium, oil and grease concentration. Germination studies was conducted with black gram seed varieties (ADT-3, ADT-5, Vamban-3, Vamban-5 and Co-6) treated with different concentrations (control, 5, $10,25,50,75$ and $100 \%$ ) of sugar mill effluent. Germination studies parameters such as germination percentage, germination index, shoot length, root length, fresh and dry weight of seedlings were found to be increased up to $10 \%$ concentration of effluent. Vigour index, tolerance index, percentage of phytotoxicity and germination index were also calculated. The above mentioned parameters were decreased with the increase of effluent concentrations (25-100\%).
\end{abstract}

Keywords: Sugar factory effluent; Physico-chemical parameters; Black gram seeds; Germination Percentage

\section{INTRODUCTION}

Environmental pollution has been recognized as one of the major problems of the modern world. The increasing demand for water and dwindling supply has made the treatment and reuse of industrial effluents an attractive option. The problem of environmental pollution on account of essential industrial growth is practical terms, the problem of disposal of industrial water, whether solid, liquid or gaseous. All the three types of wastes have the potentially of ultimately polluting water (Barman et al., 2006; Kisku et al., 2000).

Sugar industry is one of the most important agro-based industries in India and has significantly contributed to countries economy (Doke et al., 2011; Siva and Suja, 2012; Siddiqui and Waseem, 2012). As India is the largest producer of sugarcane in the world with 550 sugar mills and 220 million tons cane per year and total sugar production 13.5 million tons per year. Sugar production processing require huge amount of water for a number of steps and released almost equal quantity of effluent which contain toxic material (Kaur et al., 2010). Sugar factory effluent that has not been treated properly has an unpleasant odor when 
released into the environment. Farmers using these effluents for irrigation to reduce water demand have found that plant growth and crop yield were reduced and soil health was compromised. Because sugar industry effluents are commonly used for irrigation, it is essential to determine how crops respond when exposed to industrial effluents.

The recent studies have indicated that the effluent discharge from sugar mill consist of a number of organic and heavy metal pollutant in dissolved or suspended form that can bring about changes in the physical, chemical and physiological sphere of the biota (Salequzzaman et al., 2008). The effluents of industries has ultimate disposal in agriculture field, which can alter the soil properties and crop yielding (Baskaran et al., 2009; Samuel and Muthukkaruppan, 2011; Saifi and Singh, 2011). Seed germination studies have been made on many crops such as green-gram, Sorghum, Moong, Raphanus and Sugarcane (Doke et al., 2011, Siva and Suja, 2012). Seed germination is a critical stage that ensures reproduction and controls the dynamics of plant populations, so it is a critical test of probable crop productivity. A laboratory experiment was designed to determine the effect of different concentrations $(0-100 \%)$ of sugar industry effluent on seed germination of five varieties of black gram (Vigna mungo (L.) Hepper).

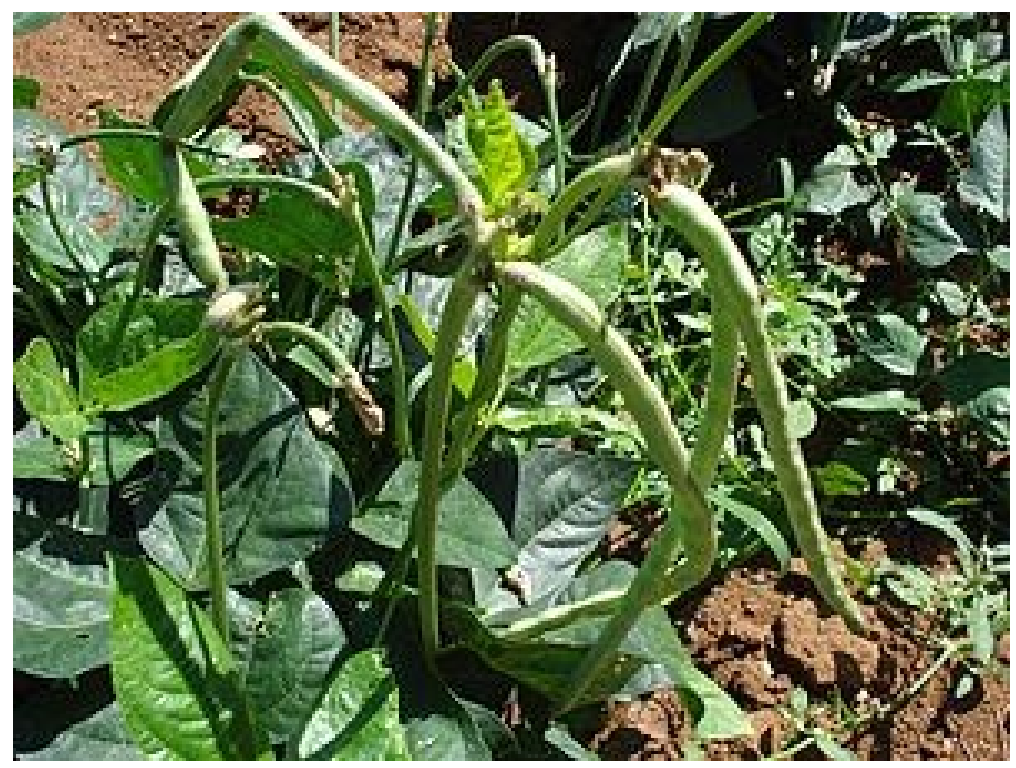

Photo 1. Vigna mungo.

\section{MATERIALS AND METHODS}

The effluent samples were collected in plastic containers from the out let of Rajasree sugar factory located at Mundiyapakkam, Villupuram district, Tamil Nadu. The collected effluent sample was brought to the laboratory for physico-chemical analysis. They were analysed by adopting the routine standard methods mentioned in APHA (1992). Five varieties (ADT-3, ADT-5, Vamban-3, Vamban-5 and Co-6) of black gram (Vigna mungo (L.) Hepper) seeds were obtained from Tamil Nadu Agricultural University (TNAU), Coimbatore. Different concentrations (Control, 5, 10, 25, 50, 75 and $100 \%$ ) of the sugar mill effluent were prepared by adding desired volume of distilled water.

The healthy and uniform sized seeds were selected and surface sterilized with $0.1 \%$ $\mathrm{HgCl}_{2}$ for two minutes. They are thoroughly washed with tap water to avoid surface 
contamination. Twenty five seeds were placed equidistantly in petridishes lined with filter paper. The seeds were irrigated with equal quantity of different concentrations of effluent and the seeds irrigated with distilled water were treated as control. Three replications were maintained for each concentration including control. The germination percentage, germination index, root length, shoot length, fresh weight, dry weight, vigour index (AbdulBaki and Anderson, 1973), tolerance index (Turner and Marshal, 1972) and phytotoxicity (Chou et al., 1978) were calculated on the 7th day's seedlings. The fresh weight of seedlings were taken by using an electrical single pan balance. The dry weights were taken after drying the seedlings in a hot air oven at $800{ }^{\circ} \mathrm{C}$ for 24 hours.

\section{RESULTS AND DISCUSSION}

Physico-chemical characters of sugar mill effluent are presented in Table 1. The effluent released from the main outlet of sugar mill was brown in color and had a smell of decaying molasses. Its brown color could be due to the presence of melanoidin, the product of sugar amine condensation and unpleasant smell due the presence of indole and other sulphur compound (Rath et al., 2010).

Table 1. Physico-chemical characteristics of sugar factory raw effluent.

\begin{tabular}{cll}
\hline S. No & Parameters & Raw Effluent \\
\hline & Physical Parameters & \\
1 & Colour & Dark brownish black \\
2 & Odour & Decaying molasses \\
3 & $\mathrm{pH}$ & 6.6 \\
4 & Temperature & $23^{\circ} \mathrm{C}$ \\
5 & Electrical conductivity total solids & 2.23 \\
6 & Suspended solids & 890 \\
7 & Total Dissolved solids & 1258 \\
8 & Biological oxygen demand & 940 \\
9 & Chemical oxygen demand & 3110 \\
& Chemical Parameters & \\
10 & Chloride as $\mathrm{Cl}^{-}$ & 705 \\
11 & Sulphate as $\mathrm{SO}_{4}{ }^{2-}$ & 62 \\
12 & Calcium as Ca & \\
13 & Oil and grease & 258 \\
\hline & All the values except $\mathrm{pH}$, colour and odour are expressed in mg/l
\end{tabular}

The $\mathrm{pH}$ was acidic in nature because of the use of phosphoric acid and sulphuric acid during clarification of sugarcane juice (Ayyasamy et al., 2008; Memon et al., 2006). It contained fewer amounts of suspended solids $(890 \mathrm{mg} / \mathrm{ml})$ and total dissolved solids (1258 $\mathrm{mg} / \mathrm{ml}$ ). The Biological oxygen demand (BOD) and Chemical oxygen Demand (COD) of the 
effluent were found $940 \mathrm{mg} / 1$ and $3110 \mathrm{mg} / \mathrm{l}$, respectively. Effluent also contained other elements such as Chloride (705 mg/l), Sulphate $(62 \mathrm{mg} / \mathrm{l})$ and Calcium $(258 \mathrm{mg} / \mathrm{l})$. The presence of considerable high value of BOD, COD and TDS whereas, Temperature, TSS and Chloride were below permissible limits noticed in the effluent. This is in conformity with the earlier finding of (Siva and Suja, 2012; Siddiqui and Waseem, 2012).

Among the five different varieties of black gram, Vamban-3 performed better under sugar factory effluent treatment and it proved to be tolerant when compared to the remaining varieties. Germination percentage, root length, shoot length, fresh weight, dry weight, vigour index, tolerance index, percentage of phytotoxicity and germination index of black gram is given in Figure 1-9.
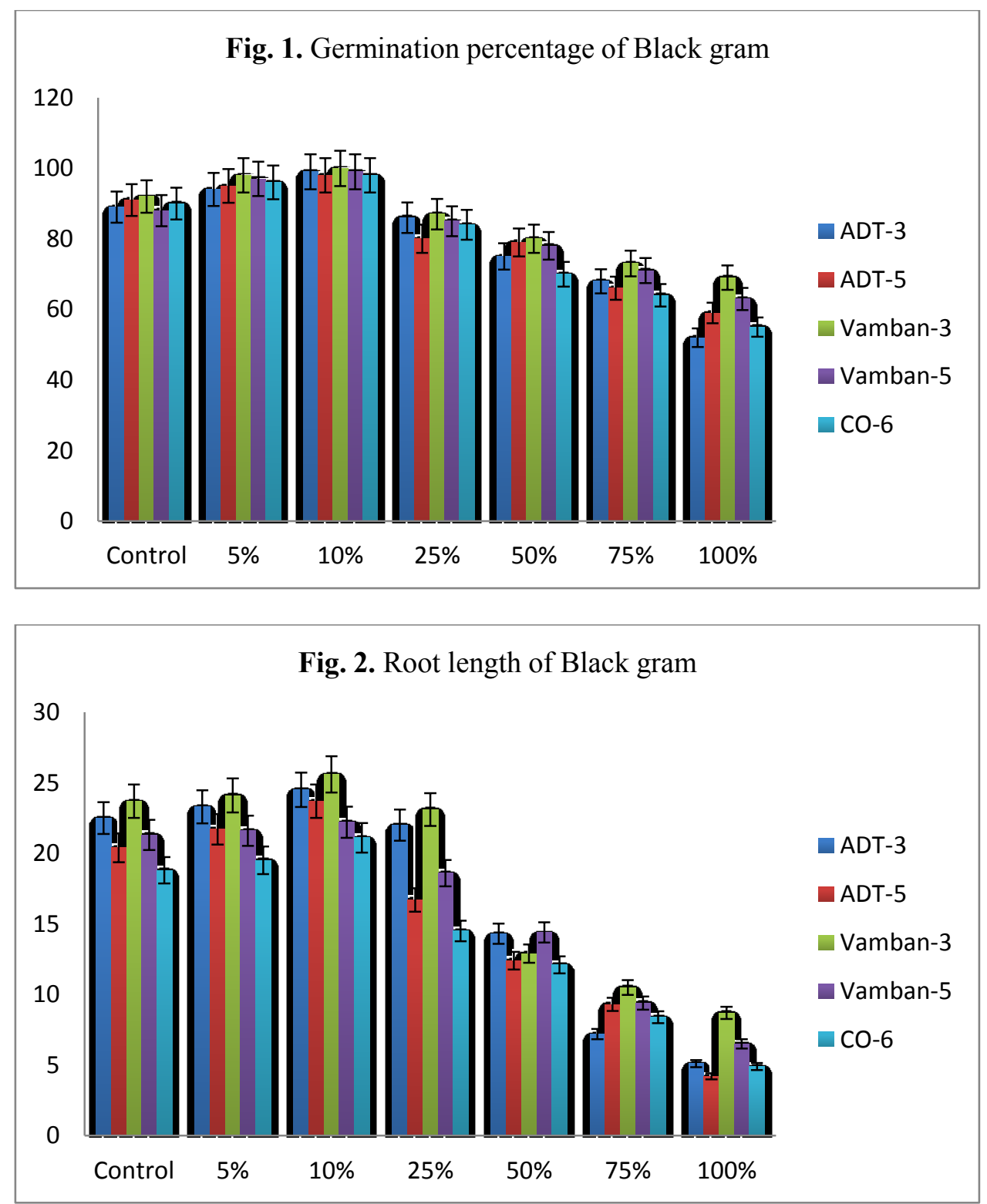

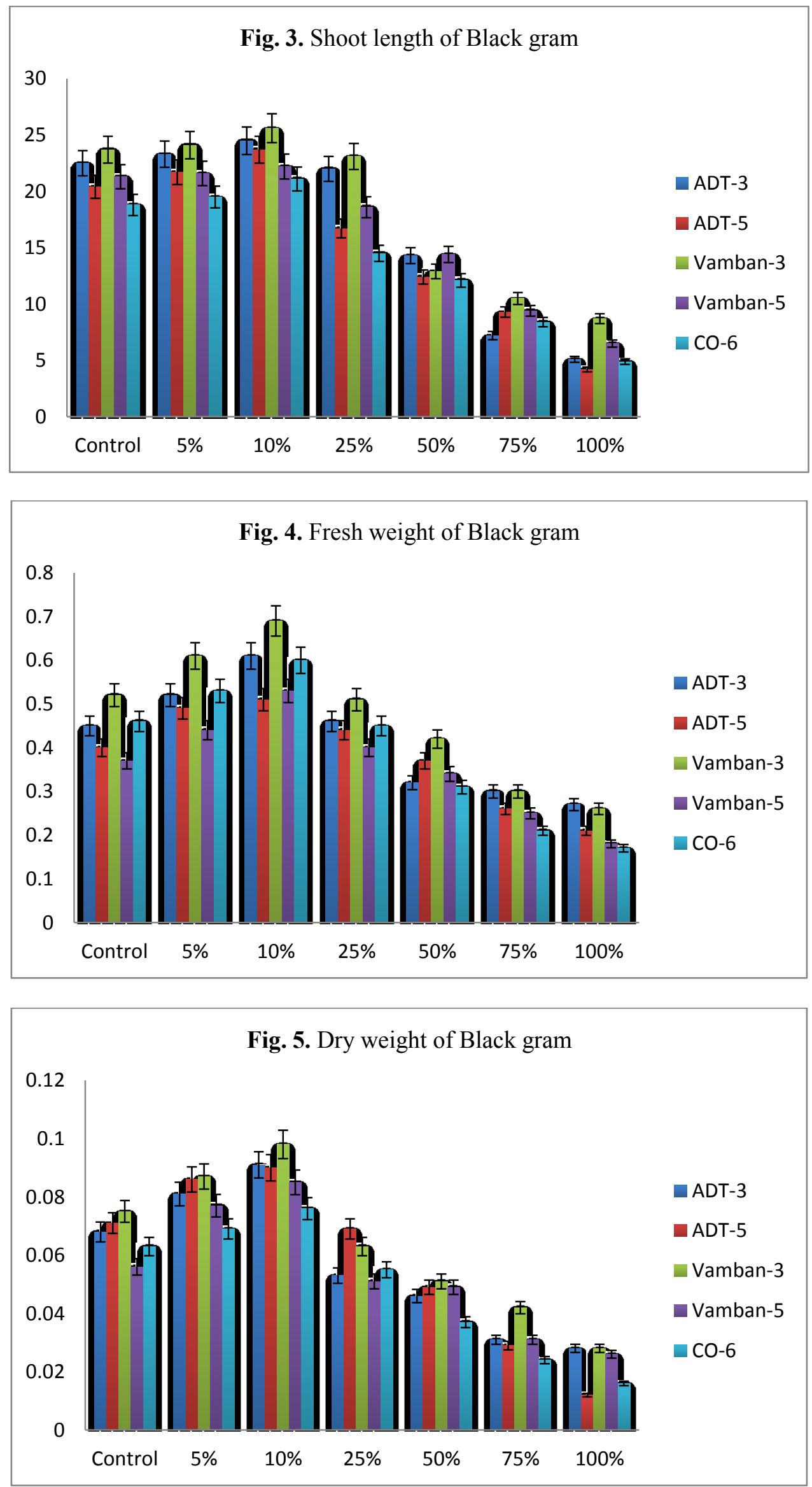

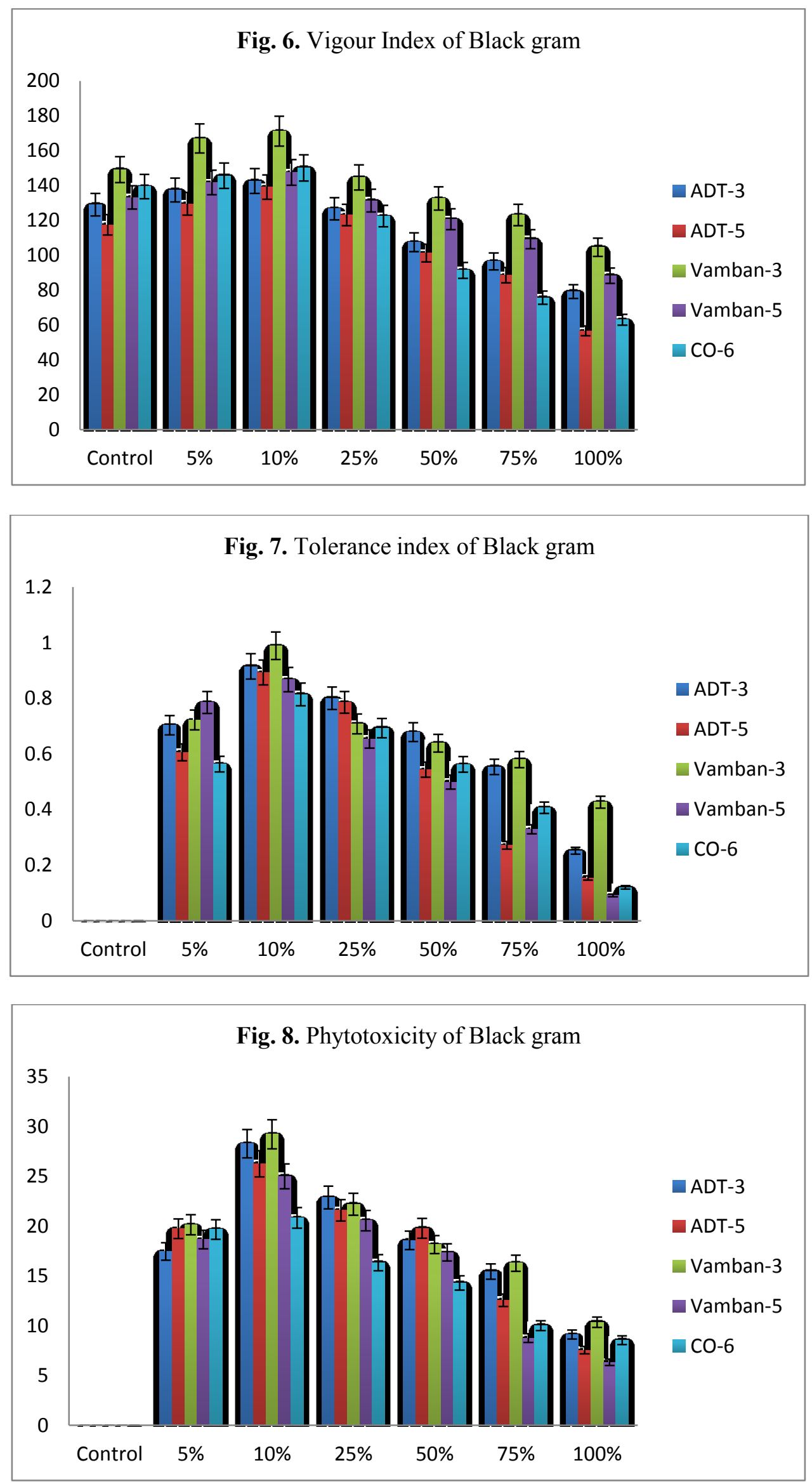


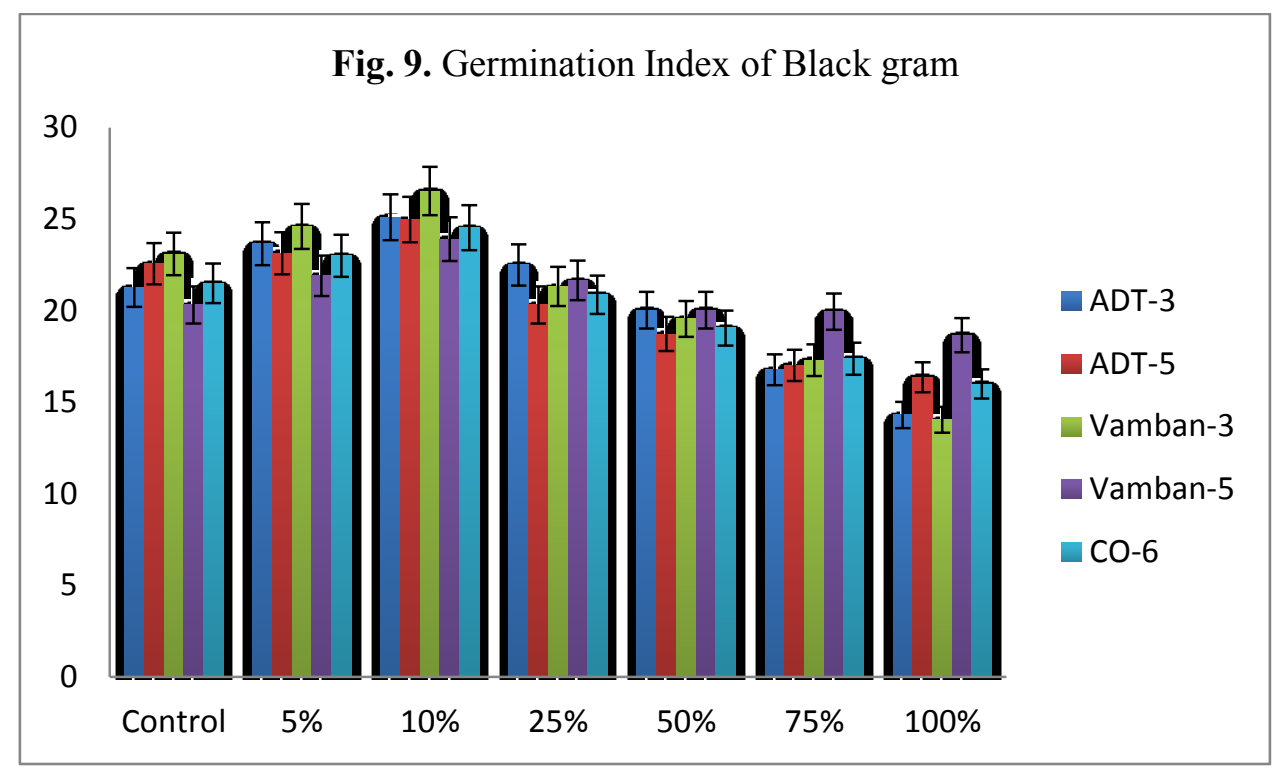

In the present study, the lower concentration (10\%) of sugar factory effluent promoted the germination percentage, seedling growth and their fresh and dry weight of black gram seedlings. But, the higher concentrations of sugar mill effluent decreased the germination studies parameters. The increase in germination percentage over control at lower concentrations indicates the stimulation of physiologically inactive seeds of the lot by the treatment as suggested by Baskaran et al. (2009). It may also be due fertilizing effect at lower concentrations and provided optimum conditions for germination (Pandey and Pandey, 2002).

The reduction in seed germination percentage under effluent treatment may be due to the higher concentration of solids in the effluent seems to be responsible for germination inhibition because the osmotic relationship of the seed and water, thus reducing the amount of absorbed water and retarding seed germination by enhanced salinity. The salt content outside the seed is known to act as a limiting factor and it might be responsible for delay in germination. Similar observations were obtained by Lakshmi and Sundaramoorthy (2000); Rajesh et al. (2013) and Vaithiyanathan et al., (2014) while studying the effect of various industrial effluents on germination studies of some agricultural crops.

The reduction in seedling growth at higher concentrations of effluent treatment may be due to the presence of excess amount of elements in the effluent. The germinating seeds under higher concentrations of effluent treatment would get low amount of oxygen which restricts the energy supply and retarded the growth and development of seedlings. The net result would be the restriction of growth of radicle and plumule (Dhanam, 2009).

Increase in seedling fresh weight and dry weight at lower concentrations of sugar factory effluent treatment was observed. The seed might have required some nutrients for their normal metabolic activities. The effluent also contains plant nutrients and trace elements which are essential for plant growth. The presence of optimum level of nutrient in the lower concentrations of sugar factory effluent might have increased the growth as well as the dry weight of seedling. The growth promoting effect of the lower concentrations of effluent was attributed to the decrease in the concentration of various chemicals present in the effluent (Barman et al., 2006 and Hayat et al., 2007). 


\section{CONCLUSION}

From the present study, it is concluded that at $10 \%$ concentration, the maximum growth is seen and it decreases as the concentration of the effluent increases. Hence it is recommended to use by the farmers living in and around the factory area to use the effluent as a liquid fertilizer for better growth of black gram (Vamban-3). Farmers are advised to use black gram (Vamban-3) as it gives high yield when compared to other varieties.

\section{References}

[1] Abdul-Baki A. A., J. D. Anderson., Crop Science 13 (1973) 630-633.

[2] APHA (American Public Health Association), Standard methods for the examination of water and waste water ( $21^{\text {st }}$ edition), Washington. (1992).

[3] Ayyasamy P. M., R. Yasodha, S. Rajakumar, P. Lakshmanaperumalsamy, P.K.S.M. Rahman, S. Lee., Bulletin of Environment Contamination and Toxicology 81 (2008) 449-454.

[4] Barman S., R. K. Sahu, S. K. Bhargava, C. Chaterjee., Bulletin of Environment Contamination and Toxicology 64 (2006) 489-496.

[5] Baskaran L., K. Sankar Ganesh, A. L. A. Chidambaram, P. Sundaramoorthy, Botany Research International 2(2) (2009) 131-135.

[6] Chou C. H., Y. C. Chaing, C. I. Rao, Bot. Bull Academic Sinica 9 (1978) 107-124.

[7] Dhanam S., Botany Research International 2(2) (2009) 61-63.

[8] Doke K. M., E. M. Khan, J. Ropolu, Shaikh, Annals of Environmental Science 5 (2011) 7-11

[9] Hayat S., A. Ahmad, A. Inam, Z. M. Iqbal Ahmad Azam, Samiullah, Pollution Research 26(3) (2007) 403-407.

[10] Kaur A., S. Vats, S. Rekhi, A. Bhardwaj, J. Goel, R. S. Tanwar, K. K. Gaur, Procedia Environmental Sciences 2 (2010) 595-599.

[10] Kisku G. C., S. C. Barman, S. K. Bhargava, Journal of Water, Air and Soil Pollution $120(2000)$ 121-137.

[11] Lakshmi S., P. Sundaramoorthy, Indian J. Environ. Ecoplan. 3(3) (2000) 501-506.

[12] Memon A. R., S. A. Soomro, A. K. Ansari, J. App. Env. Sci. 1 (2006) 152-157.

[13] Pandey A.K and G. C. Pandey., J. Indust. Poll. Control., 18(2) (2002) 175-181.

[14] Rajesh, M., K. Jayakumar, T. M. Sathees Kannan, K. Sankar Ganesh, International J. Environ. And Bioenergy 7(2) (2013) 54-62.

[15] Rath P., G. Pradhan, M. K. Mishra, Journal of Phytology 2(5) (2010) 33-39.

[16] Saifi M.A., H. B. Singh, Int. J. Chem. Sci. 9 (2011) 929-935.

[17] Salequzzaman M., S. M. Tariqual Islam, A. Tasnuva, M.A. Kashem, A. L. Mahedi, M. Masud, J. Innov. Dev. Strategy. 2 (2008) 31-35. 
[18] Samuel S., S. M. Muthukkaruppan, Int. Jr. of Pharma. \& Bio. Archives 2 (2011) 1469-1472.

[19] Siddiqui W. A., M. Waseem, Ori. J. of Chem. 28 (2012) 1899-1904.

[20] Siva S. K., P. R. Suja, Int. J. of Pharma. \& Chem. Sci. 1 (2012) 804-806.

[21] Turner R. G., C. Marshal, New Phytologist 71 (1972) 671-676.

[22] Vaithiyanathan T., M. Soundari, P. Sundaramoorthy, International Journal of Research in Botany 4(1) (2014) 15-18. 